\title{
Semiotyka dziwactwa
}

\author{
MAREK HENDRYKOWSKI \\ instytut Filmu, Mediów i Sztuk Audiowizualnych \\ Uniwersytet im. Adama Mickiewicza w Poznaniu
}

\begin{abstract}
AвsTract. Hendrykowski Marek, Semiotyka dziwactwa [Semiotic of curiosity]. „Images” vol. XXIII, no. 32. Poznań 2018. Adam Mickiewicz University Press. Pp. 231-241. ISSN 1731-450X. DOI 10.14746/i.2018.32.19.

The author assumes that the curiosity is a type of human expression. It can manifest in various languages and people's behaviors, e.g.: verbal, mimic, gestural, costume and also by props, hairstyles, makeup etc. Regardless of differences between particular manifestations of the curiosity it is always semiotic. Freaks, eccentrics and weirdos disturb human community's order and call into question established norms. They do that by their specific behaviors, appearances and individualism. They rectify, transform and change the social reality. The artistic curiosity not infrequently turn out to be the metaphor of an individual lifestyle (e.g. Witkacy, Dali). Freaks in the world of culture are not either savages or barbarians. They express themselves as well as they express their distance from the cultural system. In connection to this thesis, the author assumes that the curiosity is culture-producing.
\end{abstract}

KEYwORDs: curiosity, extravaganza, semiotics, face, film, photography, expression, behavior, manifestation, culture, norm, social norm, freedom, individual, artist, art, comedy, parody, caricature, counter culture, Internet, Facebook, symbolic interaction, network, actor, theory of actor-network

„Ludzie, którzy postępują anormalnie, niekoniecznie muszą być szaleńcami."

Elliot Aronson

\section{Wprowadzenie}

Kino, nowe media i okolice... Jedną z intrygujących przemian, jakie na przestrzeni kilku dekad dokonują się w społeczeństwach współczesnych, jest ekspansja indywidualnej i zbiorowej potrzeby widowiska. Niemal pół wieku temu francuski filozof i filmowiec Guy Debord nieprzypadkowo nadał swojej książce tytuł Społeczeństwo spektaklu[1]. Już dawno przywykliśmy do sytuacji człowieka wystawionego na widok. I do tego, że prywatny i osobisty teatr codzienności zamienia się na naszych oczach w publiczny show, którego materiałem i pożywką bywa wszystko to, co niegdyś z natury rzeczy nie było przeznaczone do wystawienia na widok publiczny. Zaskakujące, a nieraz szokujące demonstracje, o jakich tu mowa, coraz częściej epatują przeróżnymi odmianami ekscentryczności.

Czy warto zajmować się dziwactwem? Sprecyzujmy pytanie: czy warto je uważnie studiować i zgłębiać jego zagadkową semiotykę? - Z pewnością warto, $\mathrm{z}$ jednego zasadniczego powodu. Socjokulturowa przestrzeń i kulturotwórcza rola tego fenomenu stale się poszerza. Dziwactwo ciągle skupia na sobie zbiorową uwagę. Niepokorne wobec procesów wyrównawczych i presji norm unifikacyjnych powraca, odradza się i rozszerza. Pojawia się ono w coraz to innych - i coraz bardziej nieoczywistych - kontekstach kulturowych: poszukując dla siebie (nie)stosownego wyrazu, nieustannie intrygując i nie dając o sobie zapomnieć. Istnieją też inne powody i względy, o których będzie jeszcze mowa.

Dziwactwo jako przejaw współczesnego życia, zarówno na ekranie, jak i poza ekranem, nie przestaje zadziwiać. Nowe media nieustannie dostarczają mu nowych impulsów. Ostatnimi czasy fenomen masowego zalewu przeróżnych dziwactw demonstrowanych za pośrednictwem sieci każe mówić o pojawieniu się nowej kate-

[1] G. Debord, La société du spectacle, Paris 1967; idem, Commentaires sur la société du spectacle, Paris 1988. Przekład polski: Społeczeństwo spekta$k l u$, przeł. M. Kwaterko, Warszawa 2006. 
232

VARIA

gorii: dziwactwa internetowego. Uprawiane na masową skalę, współczesne dziwactwo zmieniło poniekąd swoją funkcję, przez co bardzo spowszedniało. „Robi się” je, nieustannie wytwarza i reprodukuje, aby zaistnieć w oczach innych, zwrócić na siebie uwagę i choćby na moment wyjść $\mathrm{z}$ anonimowości.

Problem w tym, że dziwactwo prawdziwie oryginalne coraz trudniej komuś przypisać, zatraciło bowiem własny podmiotowy charakter, stając się ekspresją stadną na portalach internetowych.

Żyjemy w czasach seryjnej produkcji dziwactw. Produkcja ta dynamicznie się rozwija, co oznacza, że na dziwactwo - jako towar kursujący w szerszym niż kiedykolwiek obiegu społecznym - istnieje dzisiaj niemałe zbiorowe zapotrzebowanie. Z kolei, zapotrzebowanie to skłania do wniosku, że - uchodząca w danym tu i teraz za oczywistą - sankcja społeczna, wyznaczająca granice tego, co uchodzi za normalność, również trzyma się mocno. I - mimo wszelkich przemian, jakie zaszły w ciągu kilku ostatnich dekad - nadal stanowi coś powszechnie obowiązującego.

Spróbujmy bliżej określić i zdefiniować na użytek tych rozważań pojęcie dziwactwa. Wypada zacząć od tego, że każde dziwactwo jest odstępstwem od normy, ale nie każde odstępstwo od normy jest dziwactwem. Nietypowe ludzkie zachowanie to jeszcze nie dziwactwo. Aby się nim stało, musi ono spełnić pewien ważny warunek: niejednokrotności. Dziwactwo zakłada powtarzalność, trwałość i stałość swego występowania. W niezliczonych swych odmianach może być banalne i prozaiczne (albo „poetyckie" - to dziś prawdziwa rzadkość).

Wynika z tego, że dzieli się na dwie kategorie: „artystyczną” i „nieartystyczną”. W każdej z nich obu musi jednak spełnić jeszcze jeden istotny warunek: powinno być przypisane do określonej osoby. Dziwak to ktoś! (rozpozna-

[2] B. Latour, Splatajac na nowo to, co społeczne, przeł. K. Abriszewski, A. Derra, Kraków 2010; zob. również książkę K. Abriszewskiego, Poznanie, zbiorowość, polityka. Analiza teorii aktora-sieci Bruno Latoura, Kraków 2008. walny dzięki swemu dziwactwu). W wersji zarówno ,artystycznej”, jak i „potocznej” tym, co je łączy, okazuje się podmiotowość: wyróżniający podmiotowy charakter czyjegoś działania wbrew normie - poza normą, na przekór normie panującej w danej zbiorowości.

Cóż jednak dzieje się społecznie wtedy, gdy zostaje zmultiplikowane, występując na co dzień w banalnych, seryjnych przejawach? W poszerzonej wspólnocie, dla której Internet jest bezkresną agorą, sceną i ekranem, dziwactwo w przeróżnych jego odmianach pojawia się tak często, iż można wręcz mówić - jakkolwiek paradoksalnie by to zabrzmiało - o swoistej normie pomnożonych przez tysiące użytkowników zachowań już nie tylko w ten czy inny sposób nietypowych, lecz także anormalnych i ekscentrycznych.

Szczególnie przydatna zwłaszcza do antropokulturowych analiz dziwactwa mogłaby się okazać zaproponowana przez francuskiego socjologa Bruno Latoura teoria aktora-sieci[2]. Sieciowe dziwaczki i dziwacy obsadzają samych siebie w osobiście zaprojektowanych i przeróżnie zaaranżowanych rolach, uprawiając na portalach swoistą odmianę in tera kcj o n i zmu symbolicznego, w którym człowiek usieciowiony prowadzi na oczach innych grę $\mathrm{z}$ własnym fantomem. Już choćby $\mathrm{z}$ tego jednego względu nie jest dziwactwem zajmowanie się studiami nad dziwactwem.

Kino, nowe media i okolice wchodzą w tej materii w wielopłaszczyznowy kontakt, przenikając się nawzajem. Jako fenomen psychospołeczny - i zarazem sui generis behawioralny tekst kultury - dziwactwo ekranowe (producenckie, reżyserskie, aktorskie etc.) we wszelkich jego odmianach stanowi szczególnego rodzaju formę ludzkiej autoekspresji. Wyłamując się $\mathrm{z}$ reguł systemu, może ono przybierać różnorodną postać i realizować się w rozmaitych językach oraz kodach ludzkich zachowań: słownym i pozasłownym, mimicznym, gestycznym, w kostiumie, rekwizytach, fryzurze, makijażu etc. Niezależnie od różnic w sposobie wyrażania, jedno pozostaje wspólne.

Postawmy pytanie o relację między dziwactwem a normą. Co definiuje obie te kategorie? 
Jak nawzajem funkcjonują? Czy w praktyce społecznej i socjokulturowej pozostają kategoriami absolutnie się wykluczającymi? A może wcale się nie wykluczają, lecz - jak przekonuje głębsza analiza procesu komunikowania - są w nim współobecne? Otóż mamy tu do czynienia nie z prostą dychotomią, lecz z intrygującym przyciąganiem. W rezultacie tej konfrontacji wytwarza się między nimi układ napięć na zasadzie coincidentia oppositorum. Dziwactwo nieustannie mierzy się ze zwyczajnością, więcej potrzebuje jej dla siebie. To z niej wynika zarówno jego ekscentryczny status, jak i modus operandi.

Dziwak podważa - bezkrytycznie uznawaną przez innych za coś nienaruszalnego - obligatoryjną normę. W teatrze życia codziennego i w codziennym rytuale społecznej interakcji dziwactwo stanowi rolę i rodzaj gry $\mathrm{z}$ drugimi. Jest formą performatywnego samowyróżnienia spośród innych i jako takie ma charakter semiotyczny. Co ciekawe, jego głębszy sens nie daje się opisać „wewnątrz” systemu danego języka czy kodu kulturowego. Owszem, zapisuje się w nim, przejawia i realizuje, ale się do niego nie sprowadza i nie ogranicza[3].

Ekscentryczność ma swoją cenę. Inną - jeśli jest ona „artystyczna”, inną - gdy daje o sobie znać poza sztuką i bez jej ram w życiu codziennym. I tu, i tam dziwactwo w obu swych odmianach wykazuje jednak pewną wspólną cechę. $\mathrm{W}$ performatyce codzienności i w granicach sztuki - na równi jest ono zawsze formą działania wchodzącego w konflikt $\mathrm{z}$ normą. W tym sensie każde dziwactwo (resp. czyjś demonstracyjny indywidualizm komunikowany na ekranie czy poza nim) stanowi widmo i rewers tak zwanej „normalności” (resp. społecznego przyzwolenia na akceptowaną odmienność).

Znamienną cechę dziwactwa stanowi czyjeś - mniej lub bardziej demonstracyjne - niedostosowanie. Dziwak nie chce podporządkowywać się temu, co inni uważają za powszechnie obowiązujące, "naturalne”, akceptowalne i oczywiste. Nie zamierza spełniać norm i wymagań otoczenia. Narusza swym dziwactwem powszechnie przyjęty ład wspólnoty, kwestionuje i rozsadza kursujący w obiegu zbiorowej świadomości obraz świata. Swoim niestosownym zachowaniem, postępowaniem, wyglądem, reakcją, indywidualnym sposobem myślenia i postrzegania rzeczywistości, oddziaływaniem na innych, wybrykami przekształca i zmienia społeczną rzeczywistość, wykraczając mniej lub bardziej poza to, co powszechnie przyjęte i uchodzące za „normalne”.

W miarę jak zmieniają się systemy i normy społeczno-kulturowe, wraz z nimi ewoluują również formy dziwactwa, jednak jego mechanizm pozostaje od wieków funkcjonalnie tożsamy. Dziwak to ktoś, kto - mimo wszelkich możliwych ekstrawagancji - pragnie być sobą i okazuje się sobą. Nie jest ani „wariatem”, ani "pomyleńcem”, choć za takiego może uchodzić i bywa powszechnie uważany. W studium tym interesować nas będzie nie tyle pojedynczy dziwak i indywidualne różnice zachodzące między poszczególnymi przypadkami, ile sam fenomen „dziwactwa” - ze szczególnym podkreśleniem jego kulturowych implikacji.

Synonimem polskiego wyrazu 'dziwactwo' jest mająca szacowny łaciński rodowód 'ekstrawagancja'. Zazwyczaj bywa ona definiowana jako: postawa, zachowanie się, postępowanie, wygląd nacechowany niezwykłością, odmiennością, odstępstwem od ogólnie przyjętej normy. Łaciński przedrostek 'extra' znaczy ' $z$ zewnątrz', 'nadto', 'ponad', 'od'. Jeszcze ciekawiej rysuje się etymologia czasownika 'vagor', który znaczy tyle, co 'szukam drogi', 'błąkam się'. Proponuję zachować w pamięci ten poręczny etymologiczny klucz, bowiem może nam się on jeszcze przydać w toku dalszych rozważań nad fenomenem dziwactwa i ekstrawagancji.

[3] W wydanej niedawno znakomitej książce Błazen. Maski i metafory (Warszawa 2014) jej autorka Monika Sznajderman wydobywa metafizyczny aspekt fenomenu błazeństwa. Nie kwestionując możliwości takiego ujęcia i podejścia do tematu, $\mathrm{w}$ niniejszym artykule staram się przedstawić zjawisko dziwactwa przede wszystkim jako intrygujący element psychospołeczny i socjokulturowy, z którym mamy na co dzień do czynienia. Kino współczesne odzwierciedla tu ewidentnie trendy współczesności. 


\section{Morfologia dziwactwa}

Dziwaków znał już antyk i usiłowali przeniknąć antyczni myśliciele, ale prawdziwy renesans zainteresowania nimi przyniosła epoka Odrodzenia. Za przykład weźmy postać dziwaka nad dziwakami, jakim - dla ogółu twardo stąpających po ziemi - był Ikar. Tę mityczną postać powołała wprawdzie do istnienia starożytność (Metamorfozy Owidiusza, greckie malarstwo wazowe). Jednak dopiero wieki później Pieter Bruegel Starszy wydobył z niego zaskakującą głębię wyrazu, czyniąc go modelowym w swym dramacie uosobieniem wysokich aspiracji i śmiałych dążeń człowieka ery nowożytnej[4].

Dziwacy, niepoprawni marzyciele, melancholicy, fantaści, obłąkani wynalazcy, księżycowi artyści - odgrywają w społeczeństwie specyficzną rolę osób traktowanych inaczej, mających nietypowy status.

Rozmaite inkarnacje dziwaków stanowiły intrygujący motyw kultury renesansu. Nie wszyscy, jak Ikar, usiłowali wzbić się na własnych skrzydłach ku Słońcu. Odziedziczona po średniowieczu, karnawałowa figura błazna nabiera w tamtej epoce nowego głębszego wyrazu, stając się uosobieniem dysponującej przyzwoleniem mądrego władcy krytyki społecznej (Stańczyk na dworze Zygmunta Starego). Błazeństwo w takim wydaniu ściśle koresponduje z mądrością. Jest celowo ekscentrycznym w swym wyrazie kostiumem i maską twórczo uprawianego publicznego dziwactwa: demonstrowanego w sposobie bycia, mowie, zachowaniach, kostiumie.

Dziwactwo - czymkolwiek by ono nie było - nie istnieje ani też nie może funkcjonować bez tła, z którego wyrasta i od którego odbiega. Dziwak z natury swej odróżnia się od innych, zaznacza swoją odmienność, wyróżnia się z tłumu. Inność w jego wykonaniu staje się ekspresją potrzeby bycia sobą. Dziwak okazuje

[4] Od czasów powstania dzieła Bruegla (1557) malarze następnych stuleci wielokrotnie podejmowali ten fascynujący temat. Obraz zatytułowany Upadek Ikara namalował między innymi Marc Chagall (1975). i demonstruje, że dąży do czegoś odmiennego i jest kimś innym niż ogół go postrzega (sobą właśnie). Mamy tutaj osobliwy semiotyczny paradoks. Z jednej strony, człowiek - posługując się w tym celu własnym dziwactwem - pragnie być sobą wśród innych (ale nie takich samych jak on). Z drugiej strony, cudzą inność kontestuje za pomocą własnej inności, eksponując swoje dziwactwo w oczach otoczenia.

Funkcjonalna zależność, jaka zachodzi pomiędzy intersubiektywnie postrzeganą i odbieraną przez ogół normalnością a dziwactwem, ma charakter ścisły, bezpośredni i komplementarny. Już samo pojęcie 'normy' jest językowo wpisane w 'normalność. Podobnie ma się rzecz z semantycznymi konotacjami dziwactwa ('dziwić się czemuś lub komuś,' 'dziwaczność, 'dziwność,' 'zadziwienie,' 'dziwoląg', 'dziwadło' etc.).

Jedno z drugim łączy intrygująca relacja. Dziwactwo i norma, biegunowo różne, wzajemnie się przyciągają i grawitują ku sobie. Dziwactwo jako fenomen socjokulturowy nie mogłoby występować i funkcjonować bez istnienia normy. Jest ono w życiu społecznym i w systemie kultury jej minus-obecnością. Z kolei norma społeczna - zwłaszcza jeśli mocna, powszechnie obowiązująca i nietolerancyjna - ma to do siebie, iż stymuluje dziwność, prowokuje ją i otwiera pole dla różnego rodzaju ekscentryzmów.

Paradoks tkwi w tym, że dziwactwo potrzebuje i wymaga dla swego zaistnienia normy. Istniejąca pomiędzy tymi dwoma pojęciami ścisła więź i łącząca je stała zależność przekłada się w praktyce na znamienną prawidłowość. Sprawia ona mianowicie, że im silniejsza jest presja określonej sankcji społecznej - rozumianej jako ogólnie respektowany i powszechnie obowiązujący w danym miejscu i czasie brak zgody pewnej zbiorowości na inność i odstępstwo - tym większe odpowiednio bywa prawdopodobieństwo pojawienia się i wystąpienia w jej ramach dziwactwa.

Działa tutaj pole psychospołecznych napięć i związane z nim prawo przekory, dające o sobie nieustannie znać w relacji między jednostką a społeczeństwem. Zależność tę można by sformułować następująco: im bardziej dotkli- 
wa i przemożna jest sankcja uznawanych przez ogół kryteriów „normalności”, tym bardziej samo istnienie i ciągła presja owej powszechnie obowiązującej sankcji prowokuje i skłania niektóre osoby (na przykład projektantów mody, plastyków, filmowców, ludzi teatru, performerów) do tego, żeby ją jawnie kontestować i by się jej na rozmaite - mniej lub bardziej wymyślne - sposoby demonstracyjnie przeciwstawiać.

$\mathrm{Z}$ drugiej strony, wszelkie dziwactwo ma to do siebie, że staje się dla innych natychmiast zauważalne. To jego immanentna właściwość i cecha charakterystyczna. Dziwak odróżnia się, odbiega i odcina od zwyczajnego "normalnego" tła. Widoczność fenomenu dziwactwa nie musi zatem być specjalnie podkreślana. Nawet ledwie zaznaczona i bynajmniej nie prowokacyjna, stanowi ona jego nieodłączną funkcję w zderzeniu z „normą”, wobec której - i przeciw której występuje. Nieodłączny od wszelkich postaci i form dziwactwa czynnik kontestacji otoczenia odgrywa w takich przypadkach zasadniczą rolę.

Dochodzi do tego poruszona już przez nas wcześniej - szczególnie aktualna w dobie dzisiejszej - kwestia masowego rozpowszechniania i promocji zachowań dziwacznych za pośrednictwem komunikatorów. Co tu dużo mówić: ekstrawagancja jako przekaz medialny stała się powszechnie dostępną codziennością, a przez to mocno spowszedniała i potaniała. Nadal jednak bywa atrakcyjna i pociągająca! Niewyczerpany panopticon współczesnych dziwactw należy do ulubionych materiałów wszelkich mediów: zarówno tradycyjnych, $\mathrm{w}$ rodzaju kina, radia, telewizji czy prasy, jak nowych - z internetem i telefonią komórkową na czele.

Przykłady szokujących niekiedy ekstrawagancji medialnych można by mnożyć w nieskończoność. Portal społecznościowy YouTube byłby zapewne o wiele mniej popularny, gdyby nie - bezprecedensowa w dziejach ludzkości galeria tysięcznych dziwactw, które się na nim każdego dnia zamieszcza. Można tu wręcz mówić o szalonym wyścigu bez końca, którego uczestnicy prześcigają się w niestrudzonym wymyślaniu i spektakularnych realizacjach przeróżnych ekstrawagancji.
Skoro już mowa o spektakularności... Dziwactwo jako zjawisko społeczne i spektakl adresowany do innych nie jest bynajmniej czymś nowym. Podobnie jak histeria[5], należy ono od dawna do kulturowej historii widowisk[6]. Dziwność zaskakuje, przyciąga uwagę i ekscytuje, zawierając w sobie znaczną dozę spektakularnej atrakcyjności. Niegdyś, w wieku XVIII i XIX, miejscem jej eksponowania były namioty cyrkowe, budy jarmarczne i galerie osobliwości. Wszelkiego typu curiosa, szokujące deformacje etc. nie tylko skupiały na sobie powszechne zainteresowanie, ale i stawały się przedmiotem częstokroć niezwykle agresywnej i okrutnej komercyjnej eksploatacji.

Po tamtej kulturze popularnego widowiska adresowanego do masowej publiczności kino odziedziczyło formułę nadal eksploatowanej psychosomatycznej atrakcji. Jej kulturowy magnetyzm został przez filmowców odkryty dawno temu. W duńskim filmie Atlantis reżyserowanym przez Augusta Bloma (1913) można zobaczyć niezmiernie sugestywny pokaz umiejętności człowieka bez rąk, który z niebywałą sprawnością posługuje się $\mathrm{w}$ trakcie posiłku dolnymi kończynami, zwłaszcza palcami stóp. Publiczną atrakcją rodem z galerii osobliwości był też pogrążony $\mathrm{w}$ wiecznym śnie na jawie somnambulik Cezar demonstrowany w Gabinecie doktora Caligariego Roberta Wiene (1920).

Dziwactwo - jako odstępstwo od powszechnie uznawanej za normę rzeczywistości społecznej - jest czymś niezbędnym dla jej przemiany. Porusza ono ludzkie myślenie: kwestionuje i neguje, wytrąca z zastoju i wprawia w ruch

[5] Na temat histerii, zwanej „Wielką Symulantką XIX wieku", istnieje obszerna wielodziedzinowa literatura przedmiotu, obejmująca studia nad tym zjawiskiem $\mathrm{w}$ aspekcie zarówno teoretycznym, jak i historycznym. Zob. między innymi G. Didi-Huberman, Invention of histeria. Charcot and the photographic iconographie of the Salpêtrière. Cambridge 2003; U. Baer, Fotografia i histeria: $k u$ poetyce flesza. przeł. K. Bojarska, „Teksty Drugie” $2013 \mathrm{nr}$ 4; oraz przeglądowy artykuł A. Aleksin, Augustine: króliczek Charcota, „Teksty Drugie” 2014, nr 1.

[6] Zob. G. Debord, La société du spectacle... 
236

indywidualną i zbiorową świadomość, usiłując ją nie tylko sprowokować, ale także oswoić $\mathrm{z}$ innym niż powszechnie przyjęte widzeniem (i słyszeniem) oraz pojmowaniem otaczającego świata. Zmienia przeto podejście do wielu rzeczy, czyniąc je mniej oczywistymi, niż były.

Kino, od kiedy tylko istnieje, stanowi dziedzinę z upodobaniem demonstrującą wszelkie postaci dziwactwa oraz przeróżne formy dziwności tudzież dziwaczności. Będzie jeszcze o tym szerzej mowa w toku dalszych rozważań.

W teatrze z kolei postać dziwaka jako kogoś odstającego od ogólnie przyjętej normy pojawiła się o wiele wcześniej, by przywołać tylko: Wieczór trzech króli i Sen nocy letniej Szekspira oraz Chorego z urojenia i Mieszczanina szlachcicem Moliera. Ewidentnie ekscentryczny charakter w tamtych czasach miał niemal zapomniany dzisiaj barokowy teatr masek. Kulturowe źródła dziwactwa demonstrowanego (por. etymologię słowa „monstrum”) w spektaklach teatralnych tkwią jednak o wiele wcześniej w obrzędach średniowiecznego karnawału.

\section{Dziwak na ekranie}

To niepowetowana strata nas wszystkich, że w latach dwudziestych nie doszło w końcu do aktorskiego występu Witkacego na ekranie. Intrygująca jest perwersyjna radość, z jaką „wariat z Krupówek” wychodził na spotkanie Dziesiątej Muzie, sposobiąc się sto lat temu do zagrania w filmie (chodziło o rolę profesora Głogowskiego w Mogile Nieznanego Żołnierza w reżyserii Ryszarda Ordyńskiego, 1927, którą po paru zaledwie dniach znudzony i osobiście rozczarowany porzucił).

Występ Witkacego w tamtym filmie nie doszedł ostatecznie do skutku, co w niczym nie umniejsza mistrzostwa jego wieloletnich dokonań w dziedzinie bycia sobą-innym. Na dowód, i całe szczęście, mamy zbiór kapitalnych fotografii, które własnoręcznie wykonał. Jak wyśmieni-

[7] Szerzej na ten temat: M. Hendrykowski, Witkacy, Cocteau i inni. Amatorskie filmy Augusta Zamoyskiego, „IMAGES. The International Journal of European Film, Performing Arts and Audiovisual Communication" 2017, nr 31. tym i sugestywnym był aktorem, widać najlepiej w fotografiach autoportretowych, włącznie z niezliczonymi minami i grymasami oraz słynną parodią postaci Majakowskiego z filmu Panna i chuligan. Od niedawna mamy jednak coś jeszcze! Chodzi o sensacyjne odkrycie, jakim okazał się amatorski filmik z osobistym aktorskim udziałem Witkacego noszący tytuł Tragedia na Wisła, nakręcony w zimowych plenerach Warszawy przez jego przyjaciela, Augusta Zamoyskiego[7].

Kinematografia od najdawniejszych początków swego istnienia ma niewątpliwie wielki udział w transmisji ekscentryzmów i ukazywaniu wizerunków przeróżnych dziwaków. Istnieją gatunki filmowe, które z odmienności i dziwactwa uczyniły przewodni sens i główny motyw swego istnienia. Należą do nich w pierwszej kolejności filmy wampiryczne, których historia liczy już ponad sto lat i nic nie wskazuje na to, by miała się wkrótce zakończyć. Co chwila powstają coraz to nowe wcielenia ekranowych wampirów, a wraz z nimi nowe odmiany opowieści: wcześniej, zdawać by się mogło, doszczętnie wyeksploatowanych przez poprzedników.

Ekscentryczni bohaterowie na ekranie nie są jednak tylko postaciami rodem z filmów wampirycznych. Zarówno po stronie fikcji filmowej, jak i w dokumencie, nie mówiąc już o animacji i filmach eksperymentalnych, szeroko pojęta dziwaczność i fascynująca odmienność portretowanych postaci (niezapomniane Dziwolagi Toda Browninga, 1932, galeria sylwetek kina grozy, ekscentryczne figury z filmów Buñuela, "normalni" mordercy Alfreda Hitchcocka, niejaki Trelkovsky w Lokatorze Romana Polańskiego i in.) - wszystko to wytworzyło od początku istnienia kinematografii po dzień dzisiejszy niezwykłe bogactwo form i konwencji.

Czy w grę wchodzi jakaś głębsza społeczna potrzeba? Zapewne tak. Dziwak, odmieniec, outsider, socjopata jako postać ekranowa zrobił oszałamiającą karierę w telewizji amerykańskiej kilku ostatnich dekad. Galeria dziwaków i dziwaczek obejmuje niezwykle bogaty zestaw popularnych seriali, które nie tylko bawią, ale i dają do myślenia. Należą do nich między innymi: Wszyscy kochaja Raymonda, Luzaki 
i kujony, Biuro, Rodzina Addamsów, Kroniki Seinfelda, Mad Men, Wszystkie wcielenia Tary, Simpsonowie, Rockefeller Plaza 30, The Larry Sanders Show, Glee, Pohamuj entuzjazm, Beavis i Butt-head oraz Taxi z jego niezapomnianym arcydziwakiem Louie De Palmą (pamiętana kreacja Danny’ego DeVito).

Również kino polskie ma w tej niełatwej konkurencji sporo do zaoferowania. Pierwszym $\mathrm{z}$ brzegu, choć niekoniecznie powszechnie znanym skojarzeniem, jakie przychodzi do głowy, jest dokument biograficzny Krzysztofa Gradowskiego Konsul i inni (1970). W filmie tym odbywający karę wieloletniego więzienia znany w swoim czasie oszust nazwiskiem Czesław Śliwa vel Jacek Ben Silberstein ze swadą i rozbrajającym uśmiechem opowiada przed kamerą farmazony na temat tego, w jak tandetny sposób - odgrywając w PRL rolę austriackiego dyplomaty - zdołał bez większego trudu nabrać i naciągnać na znaczne kwoty mnóstwo naiwnych ludzi: zwłaszcza wianuszek zakochanych w nim kobiet. Osiemnaście lat później Mirosław Bork nakręcił na motywach biografii Śliwy film fabularny pt. Konsul.

Mamy tu dwie komplementarne wersje tego samego bohatera: dokumentalną i fikcjonalną. Sama figura pełni jednak w obu przypadkach identyczną funkcję. W świetle prezentowanej w niniejszych rozważaniach antropokulturowej koncepcji dziwactwa jako na swój sposób wymownego przejawu autoekspresji jednostki w życiu społecznym, szczególnie ważne w obu przywołanych filmach jest - demaskatorskie $\mathrm{w}$ intencji autorów - związanie opisywanego fenomenu $\mathrm{z}$ otaczającym go przaśnym tłem peerelowskiej rzeczywistości.

Kiepska norma powołuje do istnienia równie kiepskie odmiany dziwactwa. Ekranowy portret oszusta $\mathrm{z}$ powodzeniem grasującego w PRL w ekscentrycznym wcieleniu konsula zachodniego państwa pozwala dostrzec nie tylko jego lichą rolę, lecz także realną tkankę życia społeczno-obyczajowego, na której słabościach oszust skutecznie przez lata żerował. Trzeba jednak wyraźnie zastrzec, iż dziwactwa - choć z natury swej bywa ono traktowane podejrzliwie - nie należy żadną miarą utożsamiać z szal- bierstwem tego typu kryminalnych procederów i oszukańczych praktyk.

Miłośnicy filmowej twórczości Arthura Penna pamiętają zapewne epizod z ekscentrycznym Indianinem w Małym Wielkim Człowieku (1970). Młody Czejen wyróżniał się w swoim otoczeniu tym, że chodził tyłem. Ciekawe, że ponad trzy dekady wcześniej Franciszka i Stefan Themersonowie powołali do istnienia postać, która na naszych oczach czyni coś bardzo podobnego. Co więcej, została ona wyposażona przez autorów w dającą wiele do myślenia filozofię ekscentrycznego zachowania. Mowa o awangardowej krótkometrażówce Przygoda człowieka poczciwego z 1938 roku, której bohaterem jest dziwak, na pierwszy rzut oka będący jednym $\mathrm{z}$ nas. W filmie tym zwykły poczciwiec, dystyngowany starszy pan pewnego dnia zaczyna chodzić po świecie tyłem, zarażając tym nieszkodliwym dziwactwem innych.

W filmie Themersonów, oprócz motywu chodzenia wstecz, pojawia się jeszcze inny motyw, który - w całej swojej poetyckiej prozaiczności - powoła po latach do życia inne piękne dziwactwo na ekranie. Chodzi o obraz dwóch ludzi niosących przez świat szafę. Jak powiada psycholog społeczny Elliot Aronson: „Ludzie, którzy postępują anormalnie, niekoniecznie muszą być szaleńcami”[8]. Warto zapamiętać tę intrygującą myśl. Swoje doniosłe twierdzenie autor nazywa „pierwszym prawem Aronsona”.

Przytoczony pogląd doskonale pasuje do przesłania jednego z pamiętnych osiągnięć artystycznych polskiego kina drugiej połowy lat pięćdziesiątych, jakim są Dwaj ludzie z szafa Romana Polańskiego (1958). Krótkometrażowa etiuda nakręcona na fali przemian Października przez młodego studenta łódzkiej Szkoły Filmowej, podobnie jak inne przywołane przykłady, również wpisuje się $\mathrm{w}$ mechanizm przełomu. Jej bohaterami są dwaj dziwacy, którzy - po wynurzeniu z głębin morskich - zjawiają się w naszym świecie, doświadczając w nim: obco-

[8] E. Aronson, Ludzie, którzy postępują anormalnie, niekoniecznie musza być szaleńcami, w: idem: Człowiek istota społeczna, przeł. J. Radzicki, Warszawa 1998, s. 23. 


\section{VARIA}

ści, niezrozumienia, braku tolerancji, brutalnej przemocy i odrzucenia przez społeczeństwo.

Powodem tej zbiorowej reakcji jest ich dostrzegalna na pierwszy rzut oka inność. Są nieakceptowani przez napotykanych przez siebie ludzi, ponieważ nie rozstają się z wielką trzydrzwiową szafą, którą z poświęceniem dźwigają i usiłują wszędzie wnieść. Dwójka dziwacznych intruzów przybyłych "nie z tego świata” - z ich ogromnym, nigdzie niepasującym rekwizytem - jawi się innym jako byt nie tylko zbędny, ale, co gorsza, prowokacyjnie obcy. Ekscentryczne trio, jakie ci dwaj stanowią wspólnie z szafą, nijak nie pasuje do otoczenia, wywołując natychmiast agresję lub w najlepszym razie wyniosłą obojętność.

Kilkanaście lat później, w gruntownie reformowanej w tamtym okresie stacji BBC wydarzył się niezwykły fenomen, który wkrótce zrewolucjonizował poczucie humoru milionów telewidzów nie tylko w Wielkiej Brytanii, ale także w wielu innych krajach. Grupa komików znanych jako Monty Python Flying Circus (John Cleese, Graham Chapman, Terry Jones, Eric Idle, Michael Palin i Terry Gilliam) wykreowała wspólnymi siłami już nie okazjonalne dziwactwo, ale karnawałowy świat na opak, demonstrując skalę szaleństw, z jaką mamy do czynienia w świecie współczesnym i w historii ludzkości.

Kopernikański przewrót, którego autorami są Pythoni, bierze się stąd, iż obłęd i niezliczone szaleństwa współczesnego świata, które stanowią "normę" jego funkcjonowania, zostają zderzone ze sceptycznym spojrzeniem i pełną dystansu reakcją zwykłego obywatela, którego z niezrównanym talentem zagrał (skądinąd niebywale ekscentryczny w swoim życiu osobistym) Graham Chapman. W rezultacie, to on jawi się jako ktoś "nietypowy” i dziwak, nieprzystosowany do powszechnie panujących norm życia, podczas gdy prawdziwie dziwne i wręcz zadziwiająco anormalne jest wszystko, co dzieje się wokół niego.

\section{Dziwactwo jako perwersja kultury}

Jest znamienne i dające do myślenia, że dziwactwo, parodia, karykatura i im podobne

[9] S.I. Witkiewicz, Uśmiech kretyna, w: idem: Narkotyki - niemyte dusze, Warszawa 1979, s. 333. formy wyrazu - rozkwitają szczególnie w dojrzałych fazach rozwoju poszczególnych epok kultury. W momentach, gdy, wchodząc w stadium schyłkowe, osiąga ona własną pełnię pojawia się pełen przekory duch al te r $\mathrm{n}$ a cji. Tak było u kresu Odrodzenia oraz w baroku (najpierw wspomniany teatr szekspirowski przełomu XVI i XVII wieku, później Cervantes, Molière, Defoe, Swift, Fielding, Opera żebracza Gaya), a także wówczas, gdy pojawiły się symptomy rosnącego kryzysu Oświecenia (Voltaire, Diderot, Stern czy Rudolf Erich Raspe, autor Niezwyklych przygód barona Münchhausena).

Notabene podobną prawidłowość historycznokulturową można również dostrzec w dojrzałym romantyzmie polskim (bajka O Janku co psom szył buty i dwie inne wersje historii życia opowiadane przez starego sługę w Kordianie, pewne partie Pana Tadeusza, wizerunki bohaterów i obraz świata w Nie-Boskiej komedii, Fantazym, Beniowskim).

Sytuacja z parodią, udziwnieniem, karykaturalnym obrazem rzeczywistości w funkcji symptomu aktualnego kryzysu oraz katalizatora nadchodzących przemian powtarzała się wielokrotnie - także w minionym stuleciu. Jaroslav Hašek wykreował jedyny w swoim rodzaju fenomen dobrego wojaka Švejka (1911-19171923), poprzez jego tragikomiczne losy ukazując rozpad imperium Austro-Węgier. Nie sposób pominąć w tym miejscu zagadnienia ekscentrycznych autokreacji niektórych genialnych artystów. Niedościgłym uosobieniem procesu rozkładu starej formacji w skali światowej był przywołany już wcześniej - Lord Nevermore, genialny parodysta, sejsmolog kryzysu kultury nowoczesnej, dziwak nad dziwakami, tragiczny król ekscentryków XX wieku, Witkacy.

Autor Narkotyków - niemytych dusz dysponował wytrawną wiedzą o ,zatłamszaniu intelektu" i rządach sprawowanych w życiu społecznym przez głupców. W eseju pt. Uśmiech kretyna opisywał ów fenomen jako ,jeden z elementów najbardziej zatruwających u nas wszelką twórczość i powstawanie wszelkich, choćby najmniej rzucających się nowością w oczy, rzeczy nowych" [9]. Logika jego wywodów na ten temat obejmuje nie 
tylko obronę „dziwaków” myślących niezależnie i po swojemu, lecz à rebours także - niepowetowaną społeczną szkodę wyrządzaną zbiorowości i jej kulturze przez tabuny bezmyślnych kretynów operujących argumentem „normalności” własnych poglądów na ważne tematy.

Twarze fascynowały Witkacego. Ich zarówno intrygujący, jak banalny wyraz potrafił zgłębiać w nieskończoność. „Normalność” twarzy była dla niego problematem i nieodgadnioną enigmą, której poświęcał - nie tylko jako portrecista, lecz także wytrawny fizjonomista - niemało czasu i wysiłku: „Już dziś rysowałem - pisał w liście do swej przyjaciółki Marii Pawlikowskiej - Okropne. Po co ludzie mają twarze? Co?"[10]. W tej intelektualnej zaczepce kryje się ważny podtekst, któremu na imię: podrzędność wszystkiego, co swoje i własne, względem cudzego.

Tak jest - pisze w cytowanym wyżej eseju Witkacy - ze wszystkim: zgnębić krajową oryginalność, ale przyjąć to samo z zagranicy parę lat później. Już Słowacki o tym pisał, a jest $\mathrm{z}$ tym coraz gorzej. Oczywiście uśmiech kretyna jest takim samym refleksem węzłowiska niższości jak każde napuszanie się. Zwracam nań tylko specjalną uwagę jako na wybitnie jadowitą, a pozornie, w małych dawkach, nieszkodliwą niby formę tego procederu, w którym tak celujemy. Nous autres Polonais. (...)

Więc tylko trochę mniej uporu,

Słuchajcie, ach, o kotki me.

Lepiej niech wszystko będzie według wzoru, niż żeby miało być tak bardzo „fe”[11].

Nie jest przy tym tak, że autor Pragmatystów siebie wywyższa i stawia ponad resztą. Albo że inni są „kretynami”, a jemu przypadła w udziale sama mądrość. Owszem, $\mathrm{z}$ upodobaniem testuje tzw. „normalność” za pomoca zderzania jej $\mathrm{z}$,anormalnością”. Fenomen antropologii programowego dziwactwa i wariactwa, które przez lata uprawiał „wariat z Krupówek” (był to, jak wiadomo, jeden z licznych pseudonimów, jakie sam sobie nadawał), polega na nieustannej wymianie pozycji „dziwaka” po obu stronach kultury, traktowanej jako system konfliktów i napięć. Nie jest do końca jasne i oczywiste, kto reprezentuje w naszym świecie normalność, a kto nie. Trzeba tę sporną kwestię nieustannie poruszać, testować i badać. Witkacy porusza się i krąży pomiędzy jednym a drugim. Jest obecny i nieustannie aktywny i tu, i tu. Temu właśnie służyły jego niezliczone ekscentryzmy, miny i grymasy uwiecznione na fotografiach[12].

Dziwactwo - dojrzałe i niedojrzałe - stanowi sui generis perwersję kultury. Wchodzi ono $\mathrm{w}$ nieustanną interakcję $\mathrm{z}$ jej normami przyjętymi przez wspólnotę. Stale na nowo wyznacza i redefiniuje granice tego, co dopuszczalne i powszechnie akceptowane. Gdyby użyć w odniesieniu do niego metafory ćwiczebnych manewrów: dziwactwo domaga się dla siebie istnienia osobnego terytorium, czyniąc z przestrzeni kulturowej danego miejsca i czasu swoisty poligon. Każdy system kulturowy ma bowiem charakter alternatywny w tym sensie, iż oprócz zachowań i przekazów realizowanych na co dzień zawiera w sobie także elementy potencjalne, które dochodzą do głosu w szczególnych sytuacjach lub też dają o sobie znać in potentiam - jako „druga strona”, inna droga i alternatywa uporządkowanego skądinąd systemu.

Dziwactwo, dziwność, inność, odmienność, ekscentryczność - od stuleci znajdują swój wyraz nie tylko w błazeństwie, lecz również w szyderstwach komedii, parodii i karykatury[13]. To tutaj kursujący w obiegu obraz świata - koniecznie świata realnego, a nie wyimaginowanego, irrealnego, będącego tworem czystej wyobraźni - na różne sposoby daje o sobie znać, stając się obrazem odmiennym. Wywrotowe skontestowanie tego, co ogół uważa i uznaje za ustalone i „nor-

[10] Idem, Listy do Marii Pawlikowskiej, oprac.

J. Czarnik, „Dialog” 1987, nr 1.

[11] Idem, Uśmiech kretyna..., s. 337.

[12] Zob. M.A. Potocka, Antropologia sztuki. „Ja” jako materiał twórczy; oraz S. Okołowicz, Miny Witkacego. W poszukiwaniu „wewnętrznego idioty”. Oba studia ukazały się w Katalogu Wystawy zorganizowanej w krakowskim Bunkrze Sztuki: Witkacy. Psychoholizm, red. M.A. Potocka, wybór fotografii: S. Okołowicz, Kraków 2009.

[13] Zob. noszący tytuł Parody, parodies numer specjalny czasopisma „IMAGES. The International Journal of European Film, Performing Arts and Audiovisual Communication", M. Hendrykowski, P. Pławuszewski (red.), vol. XIV, nr 23, 2014. 
malne" (czytaj: mniej lub bardziej powszechnie obowiązujące), dokonuje się za pomocą komedii, parodii i karykatury jako kulturowo akceptowanych form ludzkiej ekspresji społecznej.

Dziwak upomina się nieustannie o prawo do dziwności (resp. różnienia się). W tym sensie, będąc podmiotem wolnym i „wolność ubezpieczającym", uprawia na co dzień pewną formę krytyki społecznej. Ten umowny margines milczącego przyzwolenia jest kulturze jako nieustannie ewoluującemu makrosystemowi nie tylko potrzebny, ale wręcz niezbędny do tego, by mogła ona wytwarzać własne swobodne alternacje, których funkcja polega na wykraczaniu poza to już wytworzone, przyswojone przez ogół danej wspólnoty i uważane przez nią za „normalne”[14].

Twierdzenie, iż nie ma dziwactwa bez społecznej normy, oznacza nie tylko, że istnieje w kulturze pewien system ochronnych zabezpieczeń, ale również, że ma ona w sobie określony margines wolności jednostki w zakresie dostępnych jej form autoekspresji. Chodzi tu o istotną sferę osobistej wolności. W ustroju demokratycznym - tam wszędzie, gdzie w praktyce funkcjonowania zbiorowości istnieje szeroki zakres swobód obywatelskich - obecność dziwaków i pojawianie się zachowań ekscentrycznych jest integralnym elementem życia społecznego.

Z kolei w państwach rządzonych autorytarnie i w reżimach totalitarnych dziwactwo nie jest tolerowane, przeciwnie, bywa uważane za groźne, ponieważ oznacza samowolne odejście od panujących reguł i niesubordynację jednostki. Pod tym względem poszczególne kultury

[14] Powyższy cudzysłów wokół „normalnego” użyty został nieprzypadkowo. W życiu społecznym oprócz reguł normalnych występują także pseudo „normy” charakteryzujące się wysokim stopniem przyzwolenia na anormalność i wszelkiego rodzaju patologie, $\mathrm{z}$ bezprawiem i bezkarnością towarzyszącą łamaniu prawa włącznie. Warto podkreślić, że polskie kino współczesne (Komornik Feliksa Falka, Wesele, Dom zły i Drogówka Wojciecha Smarzowskiego, Pokot Agnieszki Holland, ostatnio Cicha noc Piotra Domalewskiego i in.) wykazuje bardzo wysoki poziom wrażliwości na ujawnianie tego typu antyspołecznych wynaturzeń i patologii. mogą się od siebie bardzo różnić. Im większa jest presja tego, co uchodzi za „normalne”, tym większe bywa prawdopodobieństwo pojawienia się dziwaków i rozmaitych „wywrotowych” dziwactw (liczba mnoga w tym przypadku jak najbardziej pożądana).

Co bardzo ważne, dziwactwo jest zawsze czyjeś. W życiu publicznym pociąga ono za sobą śmiałą, niekonwencjonalną ekspresję indywiduum, a wraz z nią osobisty wkład dziwaka w naruszenie i korektę panującego systemu obyczajowego, systemu wartości, standardów relacji międzyludzkich etc. Dziwactwo wymaga od jednostki zajęcia postawy nonkonformistycznej. Dziwak jest nonkonformistą wśród konformistów. Nie odrzuca kultury, w której żyje i na co dzień funkcjonuje. Korzystając z własnej wolności, próbuje tylko niestrudzenie poszerzać jej dotychczasowy margines w systemie kulturowym danego miejsca i czasu.

Dotąd mówiliśmy głównie o przyzwoleniu. W tym momencie dotykamy jednak innej pierwszorzędnie ważnej kwestii, jaką jest cenzurowanie dziwactwa. Oczom i uszom cenzora dziwactwo jawi się jako występek i czyn zabroniony w świetle panującej normy. Dlatego cenzura we wszelkich swych mnogich postaciach usiłuje dziwactwo na różne sposoby ograniczać, tępić i eliminować. W gruncie rzeczy bywa ona w tej roli niczym innym, jak systemowo zorganizowanym stawianiem - instytucjonalnych i pozainstytucjonalnych - barier swobodzie działań jednostki, która domaga się respektowania własnego prawa do bycia sobą, do własnej formy ekspresji i wolności wypowiedzi. Także do tego, by móc kwestionować i kontestować system kulturowy, którego jest cząstką.

Karnawał średniowieczny, staropolski etc. dawał ludziom taką wolność na czas święta, odwracając przejściowo porządek świata, aby ów - panujący w życiu danej społeczności porządek na nowo przeżyć i poprzez zabawę odrodzić w zbiorowym doświadczeniu danej wspólnoty. Tak traktowana „dziwność” i odmienność była dopuszczalna i powszechnie akceptowana, mieszcząc się w rytualnym karnawałowym porządku tamtej kultury. 
Całkiem inaczej wygląda opisane tu dążenie pod dyktaturą, gdy - narzucony przez rządy autorytarne - bezwzględny i apodyktyczny reżym jedynie akceptowanej, „właściwej”, „wzorcowej” egzystencji i bycia „jak należy”, odbiera człowiekowi jakiekolwiek prawo do realizacji własnej inności, odmienności, osobności i indywidualnej ekspresji, z dziwactwem włącznie, potępiając je, tłumiąc, piętnując i opatrując wszelkie jego przejawy, bywa że niesłychanie surową sankcją.

To ostatnie uprawnia nas do wyciągnięcia z dotychczasowych rozważań szerszego i dalej idącego wniosku, który bezpośrednio dotyczy przedmiotu naszej refleksji. Otóż rzecz nie w tym, że dziwactwo stało się powszechne, będąc dzisiaj w znacznej mierze przejawem masowej kontestacji systemu, lecz w tym, że wyraża się poprzez nie podstawowe prawo ludzkiego ,ja” do odmienności. Mamy niezbywalne prawo, by się różnić, i czynimy z niego użytek, komunikując samych siebie poprzez własną odmienność.

Dziwak od kilku stuleci nazywany bywa w Polsce odmieńcem. Trudno o trafniejsze określenie. Swoim ekscentrycznym zachowaniem nie tylko manifestuje on własną inność, ale także wnosi odmian ę. Dziwactwo podniesione do rangi artyzmu staje się w swym wyrazie metaforą sztuki życia po swojemu[15]. To, co z pełną świadomościa intelektualnego ryzyka czynię w niniejszym studium, jest niczym innym, jak oswajaniem fenomenu inności w funkcji integralnego elementu współczesnej kultury. Dziwak jako odmieniec w świecie kultury nie jest ani dzikusem, ani barbarzyńcą. Jest kimś, kto wyraża - sobą i poprzez siebie - dystans wobec systemu kulturowego, w jakim żyje, tworząc dlań alternację.

„Nawet coraz silniej zdeterminowana hierarchia systemów społecznych - twierdzi Ervin Laszlo - nie wyklucza jednostkowej samorealizacji. Samorealizacja oznacza swobodę urzeczywistniania tkwiących w nas możliwości - czyli funkcjonalną autonomię człowieka w społeczeństwie" [16].

Nośność danej kultury, jej dynamika i zdolność do dalszej przemiany polega na nieustannym poszerzaniu właściwego jej makrosystemu poprzez adaptowanie inności i odmienności, która tę kulturę wzbogaca, przekształca i w konsekwencji rozwija.

\section{B I B L I O G R A F I A}

Abriszewski K., Poznanie, zbiorowość, polityka. Analiza teorii aktora-sieci Bruno Latoura, Kraków 2008

Aronson E., Ludzie, którzy postępuja anormalnie, niekoniecznie musza być szaleńcami, w: E. Aronson, Człowiek istota społeczna, przeł. J. Radzicki, Warszawa 1998

Caillois R., Żywioł $i$ ład, przeł. A. Tatarkiewicz, Warszawa 1973

Debord G., Commentaires sur la société du spectacle, Paris 1988

Debord G., La société du spectacle, Paris 1967

Debord G., Społeczeństwo spektaklu, przeł. M. Kwaterko, Warszawa 2006

Douglas M., Ukryte znaczenia. Wybrane szkice antropologiczne, przeł. E. Klekot. Kęty 2007

Eco U., Semiologia życia codziennego, przeł. J Ugniewska, P. Salwa, Warszawa 1996

Foucault M., O pożytku $z$ wolności, w: M. Foucault, $H i-$ storia szaleństwa $w$ dobie klasycyzmu, przeł. H. Kęszycka, Warszawa 1987

Goffman E., Analiza ramowa. Esej z organizacji doświadczenia, przeł. S. Burdziej, Kraków 2010

Goffman E., Człowiek w teatrze życia codziennego, przeł. H. Datner-Śpiewak, P. Śpiewak, Warszawa 2000

Jung G.C., Typy psychologiczne, przeł. R. Reszke, Warszawa 1997

Kępiński A., Melancholia, Warszawa 1974

Lakoff G., Johnson M., Metafory w naszym życiu, przeł. T.P. Krzeszowski, Warszawa 1988

Laszlo E., Systemowy obraz świata, przeł. U. Niklas, Warszawa 1978

Latour B., Splatajac na nowo to, co społeczne. Wprowadzenie do teorii aktora-sieci, przeł. K. Abriszewski, A. Derra, Kraków 2010

Sznajderman M., Błazen. Maski i metafory, Warszawa 2014

Witkiewicz S.I., Uśmiech kretyna, w: S.I. Witkiewicz, Narkotyki - niemyte dusze, Warszawa 1979

[15] G. Lakoff, M. Johnson, Metafory w naszym $\dot{z} y c i u$, przeł. T.P. Krzeszowski, Warszawa 1988. [16] E. Laszlo, Systemowy obraz świata, przel. U. Niklas, Warszawa 1978, cyt. s. 134; R.K. Merton, Teoria socjologiczna i struktura społeczna, przeł. E.M. i J. Wertenstein-Żuławski, Warszawa 1982. 